\title{
The New European Audit Firm Rotation
}

\section{Patrick Velte}

Professor for Accounting \& Auditing, Leuphana University Lueneburg, Germany

*Corresponding author: Patrick Velte, Professor for Accounting \& Auditing, Leuphana University Lueneburg, Germany, Tel: 04131 677-2117; E-mail: patrick.velte@leuphana.de

Rec Date: Sep 22 2014; Acc Date: Sep 25 2014; Pub Date: Oct 022014

Copyright: () 2014 Velte P. This is an open-access article distributed under the terms of the Creative Commons Attribution License, which permits unrestricted use, distribution, and reproduction in any medium, provided the original author and source are credited.

\begin{abstract}
The European legislator has introduced a mandatory audit firm rotation principally after ten years and with regard to a cooling off period of four years to increase auditor independence. This kind of external rotation complements the existing internal mandatory rotation (auditor rotation). This paper implies a critical review of the economics need of rotation rules. In contrast to the perception of the European standard setter, mandatory external rotation will not automatically lead to an increased financial accounting and audit quality.
\end{abstract}

Keywords: Corporate governance; Audit quality; Empirical audit research; Auditor independence

\section{Introduction}

In the wake of the financial crisis, regulators and shareholder activists alike have been revisiting the issue of auditor independence with a view towards requiring companies to periodically rotate their outside audit firms. Facing the capital markets' shrinking trust in the decision usefulness of financial accounting and auditing as a result of the financial crisis, the European legislator has finalized the audit reform this year. The aim of the regulation is to increase audit quality by reducing the expectation gap, to increase auditor independence and to prevent further audit market concentration. In order to increase auditor independence, based on independence in fact as well as in appearance, an external rotation (audit firm rotation) principally after ten years and with regard to a cooling off period of four years is mandatory for public interest entities now. While internal rotation (auditor rotation) stipulates changes within the audit firm, external rotation replaces the audit firm entirely, following a fresh start approach. In light of the recent explosiveness caused by the European audit reform as well as various forms of rotation from an international point of view, the assumption of a positive link between external rotation and quality of financial accounting and auditing is to be subject to further scrutiny.

\section{Theoretical Foundation}

Audit firm rotation is often considered a way to enhance audit quality due to a prevention of the auditor's depending relationship with the management, distinguishing between the auditing of capital market oriented and non-capital market oriented corporations. Since traditional agency conflicts are characteristic in large management operated corporations, the necessity of a statutory rotation is solely related to this group of companies. Shareholders in small and mediumsize companies are to exert greater influence on the management than an average private shareholder in a public company. Burton and Roberts present a fundamental approach to the economic impact of auditor changes [1]. Although, considering the assistant role of an auditor in a stock corporation, a long-term contract between board and auditor seems sensible, the independence in appearance might be limited due to a special trust relationship between management and auditor in a long-term assignment. They suggest that personal relationships between auditor and management, the combination of auditing and consulting, as well as the auditor's goal of maintaining the assignment are determining factors towards reducing audit quality.

According to DeAngelo [2], quasi-rents according to low balling without compulsory rotation might present a financial incentive to the auditor to give up his independence, if the probability of exposure by the capital market is considered to be low. According to supporters of this theory, an auditor's low balling strategy which might be related to his lack of independence can be counteracted by compulsory rotation. Chi et al. [3] do not agree with this opinion but state an adverse effect on independence in fact due to rotation under the existence of quasi rents and assignment by the owners. They point out that the auditor would give up his independence in the last audit period before the rotation because he assumes hidden transfers of the management since he no longer has to be concerned about the loss of quasi rents due to shareholders not being re-elected. According to Bigus and Zimmermann [4], the absolute (client related), but not necessarily the relative quasi rents are cut short due to rotation, which implies that rotation does not necessarily cause an increase of auditor independence. Irreconcilable differences of opinion between management and auditor are not risky to the auditor if a change is scheduled for the near future anyway, which is mentioned as another possible advantage. Literature assumes stricter and more relentless auditing under compulsory rotation, considering that the auditor wishes to diminish the risk of having his successor complain about his low performing upon review of previous years' audits. Finally the avoidance of organizational blindness under compulsory rotation is pointed out, as negatively influencing the audit efficiency, even under observation of independence. Hence, the auditor simply trusts his results from previous years instead of anticipating important changes in the company development and adjusting his auditing strategy.

The positive effects of compulsory audit firm rotation on the limitation and avoidance of low balling as mentioned in literature are not secured, since rotation creates system immanent disadvantages. Thus, a change of auditor incurs a higher monetary value of auditing costs and increased audit fees which result in additional costs of the initial audit and transaction costs on the part of the client. Especially long-term audit scheduling and following up on complaints or auditors' suggestions from previous audit periods would have to suffer under rotation. Empirical surveys in the US show that the auditor's risk of liability is significantly higher in first or second audits than in following audits. Since first audits tend to be of lower quality, negative responses of the capital market are to be expected upon a forced 
change of auditor. This way an investor can no longer distinguish a voluntary change of auditor due to opinion shopping of the management from a compulsory rotation, which increases his cost of information. Therefore, for corporations which aim to offer high audit quality to the capital market, compulsory rotation in short intervals may be unfavorable. Even a statutory long-term rotation cycle (e.g. more than nine years) cannot prevent the risk of hidden intention of management.

Audit market concentration is another important disadvantage of compulsory rotation. The European audit market for listed companies is dominated by the Big Four audit firms. The reason for this concentration lies in the Big Four companies having the highest experience value in auditing capital market oriented enterprises, according to DeAngelo [5] they are related to a higher quality and independence, and have an extensive potential of resources in additional performances such as advisory services to show. This development of oligopoly in the global audit market makes an entry into the market very difficult for small and medium-size audit firms. In general, these difficulties cannot be overcome by compulsory rotation, since changes are made within the audit firm (internal rotation) or between Big Four audit companies (external rotation). Furthermore, practical experience suggests frequent changes from small to larger audit companies. In general view, the above mentioned impacts under rotation by a change of the audit company as opposed to a change of auditor within the company are stronger. The overall impact of compulsory rotation is, from a theoretical point of view, not explicit, therefore, even with the auditor applying low balling, a rotation does not necessarily imply higher quality but the interruption or shortfall of learning and experience effects can have an altogether negative effect on the quality of financial accounting and audit.

\section{Empirical Rotation Research}

The empirical surveys on audit firm rotation mainly relate to the US capital market. The majority of empirical assessments disapprove of audit firm rotation, since there are either no effects or even negative effects on the quality of accounting and auditing detectable. Dopuch et al. [6] State that in case of audit without external rotation it is more likely that the auditor over time biases approval testate accommodating the management, and conceals errors from the public. In the experiment at hand, however, experience effects of the auditor under a long-term assignment remain uncovered. Davis et al. [7] point out that the management takes advantage of its leeway in decisions and arrangements in short (two to three years) and very long duration of assignment (at least thirteen years) in order to fulfill or outdo result prognoses. The latter is considered positive by the capital market and may reflect in a higher demand of shares. The authors prove that the duration of the audit assignment has a positive effect on the extent of maximum earnings management, so that the audit quality is increased by external rotation after a longer duration. Boone et al. [8] stress signs of interdependence between external auditor rotation and risk margin on allocated capital contribution. Capital costs decrease in the first years of the assignment and rise with its duration.

As outlined above, the majority of recent studies either does not show proof or documents a tendency of weakening the quality of accounting and auditing due to external rotation. Johnson et al. [9] saw comparatively short assignments (two to three years) causing higher training costs combined with a lower quality of accounting, while they did not find proof of lower quality in long-term assignments (at least nine years). Myers et al. [10] report that auditors in long-term assignments (more than five years) disapprove of a maximum accounting policy due to learning and experience effects. Likewise, AlThuneibat et al. [11] state a negative correlation between external rotation and the quality of accounting. In their survey, Ghosh and Moon [12] show that investors, rating agencies and analysts assume positive interdependence between the duration of assignment and the quality of accounting, represented by the interest rate investors require, rating results, as well as the analysts' performance prognoses.

Mansi et al. [13] question the usefulness of audit firm rotation and state negative capital market responses in the assessment of marketnoted stocks of risk intensive companies. Therefore, with greater entrepreneurial risk, investors tend to rate the auditor's learning and experience effects in a long-term audit assignment higher than possible limitations of his independence. Likewise, Knechel and Vanstraelen [14] show that independence in appearance of the capital market does not decrease with extended assignments. Azizkhani et al. [15] see the duration of assignment in an inverse relation to the size of capital costs, whereas there are no significant changes under external rotation. Fargher et al. [16] are among the few surveys which compare the impact of internal and external rotation. They prove that in the first years after a change of auditor the management lowers the extent of accounting policy if internal rotation has taken place. Under external rotation, however, a significant increase of discretionary periodical classification is established.

\section{Conclusion}

Auditor independence is an indispensable requirement in providing appropriate quality of financial accounting and auditing. In order to strengthen independence, audit firm rotation has been the new regulation instrument by the European legislator. Since the EC provides neither a theoretically nor an empirically grounded economic justification for the reforms in question, the effect of external rotation on the quality of financial accounting and auditing is uncertain. An overview shows that an enhancement of auditor independence will not necessarily be achieved by the new rotation rules. It might be paid for by an interruption or lack of learning and experience. Empirical studies often do not show an increased quality of financial accounting and audit under external change of auditors. Insofar, the economic need for this audit market regulation is still controversial.

\section{References}

1. Burton JC, Roberts W (1967) A study of auditor changes. J Accountancy 123: 31-36.

2. DeAngelo LE (1981) Auditor independence, "low balling" and disclosure regulation. J Account Econ 3: 113-127.

3. Chi W, Yu H, Chiu S (2004) Mandatory rotation and auditor independence. Taiwan Accounting Review 5: 71-104.

4. Bigus J, Zimmermann RC (2007) Unabhaengigkeit und Regulierung von Abschlusspruefern. German Working Papers in Law and Economics. Osnabrueck.

5. DeAngelo LE (1981) Auditor Size and audit quality. J Account Econ 3: 183-199.

6. Dopuch N, King RR, Schwartz R (2001) An experimental investigation of retention and rotation requirements. J Account Res 39: 93-117.

7. Davis LR, Soo BS, Trompeter GM (2009) Auditor tenure and the ability to meet or beat earnings forecasts. Contemporary Accounting Research 26: 517-548.

8. Boone JP, Khurana IK, Raman KK (2008) Audit firm tenure and the equity risk premium. J Account Auditing Financ 23: 115-140. 
9. Johnson VE, Khurana IK, Reynolds JK (2002) Audit firm tenure and the quality of financial reports. Contemp Account Res 19: 637-660.

10. Myers JN, Myers LA, Omer TC (2003) Exploring the term of the auditorclient relationship and the quality of earnings. Account Rev 78: 779-799.

11. Al-Thuneibat AA, Al Issa RTI, Baker RAA (2011) Do audit tenure and firm size contribute to audit quality. Managerial Auditing Journal 26: 317-334.

12. Ghosh A, Moon D (2005) Auditor tenure and perceptions of audit quality. Account Rev 80: 585-612.

13. Mansi SA, Maxwell WF, Miller DP (2004) Does auditor quality and tenure matter to investors? J Account Res 42: 755-793.
14. Knechel WR, Vanstraelen A (2007) The relationship between auditor tenure and audit quality implied by going concern opinions. Auditing 26 : 113-131.

15. Azizkhani M, Monroe GS, Shailer G (2007) Auditor tenure and perceived credibility of financial reporting. Working Paper. Canberra.

16. Fargher N, Lee HY, Mande V (2008) The effect of audit partner tenure on client managers' accounting discretion. Managerial Auditing Journal 23: 161-186. 